\title{
The Impact Of Breast Self Examination Education On Breast Self Examination Practice Among The Women In Rural Community Lahore Pakistan
}

\author{
Iqra Aqeel *, Miss Iram ** \\ * Lahore School of Nursing, Name of organization, The University of Lahore, Lahore, Pakistan \\ ** Dept. Lahore School of Nursing, Name of organization, The University of Lahore, Lahore, Pakistan \\ DOI: 10.29322/IJSRP.12.01.2022.p12136 \\ http://dx.doi.org/10.29322/IJSRP.12.01.2022.p12136
}

\begin{abstract}
Background: breast cancer is the most common type in women. In Pakistan, one in nine women develops breast cancer at some stage of their life. Both the cause of breast cancer and the means for its cure are unknown. To date there is no recognized way to prevent breast cancer. The only proven risk factor for breast cancer is age with incidence rising sharply after age 40. Early detection and treatment are the best protection. Practicing health behaviors that promote early detection then becomes a priority for women age 50 years and over who, because of their age, are considered most at risk for developing breast cancer.

Methods: A quasi-experimental one group pre- test and post- test research design was used for this study. The study was carried out among 50 women of Ali Raza Abad Lahore, selected by convenient sampling method. Data was collected by using structured questionnaire.

Results: the overall pre-test knowledge mean score was found to be 4.55 as compared to post-test knowledge score which was 5.34. Significant effect of health

Education program was found as $p$ value was (.000).

Conclusion: Based on the findings of the present study, concluded that breast self-examination education influenced practices. An educational program on Breast self-examination has positive effect on breast self- examination practices.
\end{abstract}

Index Terms- Breast self-examination, Impact, Practice, Cancer

\section{INTRODUCTION}

M any diseases are in women who are affecting the women health but, breast cancer among the women is rapidly increasing worldwide. Breast cancer is commonest cancer in the females. All over the world, every year round about 1 million cases of breast cancer newly diagnosing and over 600,00 deaths occurring due to breast cancer (Tabari, Abbaszadeh, Torabi, \& Amini, 2017). World Health Organization in 2008, announced 1.3 million new cases and 458000 deaths from breast cancer in females all over the world (Sarwar, Shah, Yousaf, Ahmad, \& Khan, 2015)

According to American Cancer Society in 2012, 1.7 million cases of breast cancer and 521,900 deaths among them were reported (Mone \& Kharde, 2018). In Asia, unluckily Pakistan is on top after the Israel in breast cancer. Breast cancer also 2.5 times greater than the other neighboring countries (Anjum, Razvi, Maqbool, \& Jahan, 2017). The annual incidence rate of breast cancer in Pakistan of 2012 was 50.3/100,000 (Badar et al., 2015). In Pakistan an aggregate of 11,853 breast cancer were recorded in all age-gatherings, both sex joined in a 18-year day and age between December 29, 1994 and December 31, 2012 (Badar et al., 2015).

Breast cancer is a threatening multiplication of epithelial cell coating the channels or lobules of the breast, which may have differing results and reactions to treatment contingent upon the early detection (Eittah, Awed, \& Bukhary, 2014). Breast cancer is a harmful expansion of epithelial cell coating the duct or lobules of the breast, which may have differing results and reactions to treatment contingent upon the early detection (Eittah et al., 2014). Prescribed age to start BSE is 20 years, and instructing young females about BSE is basically significant to help them to deal with themselves and lower their risk of breast cancer (Mone \& Kharde, 2018). Breast self examination is a straightforward, minimal effort, noninvasive with no unique material/instrument necessities and it is a demonstrative technique for breast cancer which just takes five minutes to apply (Ayed et al., 2015).

Breast Self Examination is a one of a kind strategy since it is reasonable, noninvasive, takes the slightest time and physical energy and is the main method for breast cancer screening for women who don't have satisfactory access to wellbeing care. BSE use for early detection and treatment of breast cancer (Tabari et al., 2017). Breast self-examination (BSE) is a method do to search for changes or issues in the breast. Breast Self Examination (BSE) encourages women to acclimate themselves with how their breast look and feel, so they can distinguish any progressions and ready wellbeing experts early. Adult of any age are urged to perform BSE at any rate once per month. Premenopausal ladies ought to do it on day 5 to day 7 of the menstrual cycle, and once month to month for postmenopausal ladies(Muchirevesi, 2016).

It' s really important to guide the women to perform regular breast self examination of themselves monthly. Many women does not follow these instruction(Ayed et al., 2015). If women use BSE regularly on monthly basis, they will be able to find a lump on early stage and early diagnosis will be help in treatment(Ayed et al., 2015).

There are six step of performing breast self examination effectively. In the first step, women stand in front of mirror put hand on hip and observe the breast for change. This position will 
help to easily visualize the breast. Look the breast for any growth, dimpling, scaring, erosion of skin, color of skin and bruising. In the second step, women stand in front of mirror, raise both hand and observe the changes in breast like dimpling, scaring, bruising and erosion. In the third step, women stand in front of mirror, see the nipple for any discharge like watery, milky, or yellowish discharge by squeezing the nipple. In the forth step, just lay down straight in spine position, raise one arm above and use three middle fingers pad of other hands to find any lump with light pressure by rotational movement on entire breast. In the fifth step, women examine the breast either in laying or standing position by palpate the whole breast in rotational movement for any change like lump or enlarge lymph node(Muchirevesi, 2016).

\section{AIMS OF THE STUDY}

The purpose of the study is to assess the impact of breast self examination education on breast self examination practice among women of rural community Lahore. SIGNIFICANCE OF THE STUDY

It' $s$ really important to overcome the disease of breast cancer among women, women are the major part of society and breast cancer is spreading 1:8 women. Therefore it' $\mathrm{s}$ important to enhance the practice of breast self examination among women and with the help of this breast cancer can be early detect and treat soon at early stage.

\section{(I)LITERATURE SEARCH}

A study was conducted to evalate the knowladg and techniques of breast self examination among girls regarding early detection of breast cancer. The study showed that, breast cancer is increasing continuely because of low level of knowladge and awarness about the diferent mathods to detect breast cancer. Breast self examination is such a detection mathod of breast cancer which every women can easily and regulary used. The educational and demonstration program on awareness and significance of BSE should be introduced among young adult girls which can help them in early detection of breast cancer(Mone \& Kharde, 2018).

A study was conducted to enhance the breast self-examination in terms of knowledge, attitude, and practice among females. Breast self examination is a straightforward, minimal effort, noninvasive with no unique material/instrument necessities and it is a demonstrative technique for breast cancer which just takes five minutes to apply. The result of the study showed that most of the female have very poor knowledge and practice toward breast self examination. There was found that media plays very imperative way of information to enhance the practice of breast self examination(Ayed et al., 2015).

A study was done to see the effect of health education on raising female awareness' regarding breast cancer. According to this study breast cancer is a great problem among the females disease. Breast cancer is life threatening condition for women if it is not detected earlier. Its late diagnosis is worse condition and its prognosis is very poor at late stage. The awareness on breast cancer program is a essential tool to battle with the early breast cancer detection and to minimize the mortality and morbidity rate. Doing month to month breast self exam (BSE) is an incredible method to be comfortable with the breast' surface, recurrent changes, size, and skin condition. The general changing highlights of breast cancer are, for example, swelling or bump (mass) in the breast, swelling in the armpit (lymph hubs), areola release (clear or grisly), torment in the areola, upset (withdrew) areola, flaky or set skin on areola, relentless delicacy of the breast, and irregular breast agony or uneasiness(Eittah, Awed, \& Bukhary, 2014).

A study was conduct to assess the knowledge and practice of breast self examination among females. The study showed that breast self examination is very important tool of health care of women to put a stop to breast cancer. In this study different step of breast self examination explained. The six step of performing breast self examination effectively. In the first step, women stand in front of mirror put hand on hip and observe the breast for changes. This position will help to easily visualize the breast. Look the breast for any growth, dimpling, scaring, erosion of skin, color of skin and bruising. In the second step, women stand in front of mirror, raise both hand and observe the changes in breast like dimpling, scaring, bruising and erosion. In the third step, women stand in front of mirror, see the nipple for any discharge like watery, milky, or yellowish discharge by squeezing the nipple. In the forth step, just lay down straight in spine position, raise one arm above and use three middle fingers pad of other hands to find any lump with light pressure by rotational movement on entire breast. In the fifth step, women examine the breast either in laying or standing position by palpate the whole breast in rotational movement for any change like lump or enlarge lymph node(Muchirevesi, 2016).

A study was carried out on barriers of breast selfexamination. The breast self-examination turns out to be more critical and applicable and can be considered as a technique for enhancing the strength of adult women. BSE is a technique utilized by women at home to scan for changes in the breast tissue. American cancer Society prescribed that women ought to begin getting prepared on month to month BSE at 20 years old(Tabari et al., 2017).

A study was performed on breast self examination in term of learning, state of mind and practice. The point of this investigation was to survey the BSE learning, mentality and practice. Breast self examination is simple and minimal effort device to distinguish bosom breast cancer early. BSE is viable technique and it take just 5 minutes to apply(Ayed et al., 2015).

A study was conduct on knowledge, attitude and practices amongst the females towards breast cancer screening program. According to this study there is low survival rate for three months or more seasoned introducing symptomatic breast tumors, and dominant part of Pakistani females detailed late. Few examines exploring individuals' convictions have been conveyed out in Pakistan and those done in western settings have accentuated the significance of these screening apparatuses and shown poor mindfulness about breast cancer and screening techniques, restricted assets, absence of training, social, religious and poor discernment towards screening. The study indicates evident absence of learning with respect to breast cancer and its screening, and generally rehearses about BSE are extremely poor( $\underline{\text { Sarwar, }}$ Shah, Yousaf, Ahmad, \& Khan, 2015).

\section{METHODS}

STUDY DESIGN; Experimental study design will be used. Settings: Study will be conducted in the community of Ali Reza Abad, Raiwind road Lahore.

DURATION OF STUDY: The study will be done in 4 months from September 2018 to December 2018. 
Target population: The target population included in my study will be females 20 to 5o years of age and had no history of diagnosed breast cancer.

SAMPLE SIZE: The sample size will be 50 women.

SAMPLE TECHNIQUES; Random sampling technique will be use in this study.

INCLUSION CRITERIA: Inclusion criteria of study involve; The 20-50 years age of women. Women had no history of diagnosed breast cancer.
EXCLUSION CRITERIA: Exclusion criteria of study involve The women have diagnosed breast cancer. Males not included. Women who are not willing to participate cannot participate in this study STUDY TIMELINE

The data was collected from September, 2018 to January, 2019. ETHICAL CONSIDERATION

Each member who will participant in this study will be dealt in respective way. All information will be confidential. Volunteer right will be maintained.

\section{RESULT}

Research Question - is to assess the impact of breast self examination education on breast self examination practice among women.

Table 1; description of demographic characteristics

\begin{tabular}{|l|l|l|l|}
\hline Characteristic & Category & \multicolumn{2}{|c|}{ Respondents } \\
\cline { 3 - 4 } & & Number & Percentage \\
\hline \multirow{3}{*}{ Marital status } & Single & 38 & 76.0 \\
\cline { 2 - 4 } & Married & 12 & 24.0 \\
\hline \multirow{5}{*}{ Age } & $15-25$ & 13 & 26.0 \\
\cline { 2 - 4 } & $26-35$ & 09 & 18.0 \\
\cline { 2 - 4 } & $36-45$ & 14 & 28.0 \\
\cline { 2 - 4 } & $46-55$ & 14 & 28.0 \\
\hline \multirow{5}{*}{ Gender } & Female & 50.0 & 100 \\
\cline { 2 - 4 } & Male & 0 & 0 \\
\hline \multirow{5}{*}{ Occupation } & Student & 41 & 82.0 \\
\cline { 2 - 4 } & Working & 08 & 16.0 \\
\cline { 2 - 4 } & House wife & 01 & 2.0 \\
\hline
\end{tabular}

The classification of women according to age, marital status, gender and occupation show above in table 1.

Table 2.1; average of pre and post mean

\begin{tabular}{|l|l|l|l|l|}
\hline Average pre men & Average post mean & Average pre SD & Average post SD & $\begin{array}{l}\text { Difference } \\
\text { mean }\end{array}$ \\
\hline .2407 & .9867 & .17137 & .38388 & 0.746 \\
\hline
\end{tabular}

Table 2.2; pre and post knowledge and practices mean and SD of women regarding breast self examination

\begin{tabular}{|l|l|l|l|l|l|l|}
\hline Ser \# & Question & M1 & M2 & SD1 & SD2 & Diff \\
\hline 1 & $\begin{array}{l}\text { During the past 3 months, how many times } \\
\text { did you examine your breasts for cancer? } \\
\text { Did you? }\end{array}$ & .00 & 1.00 & .00 & .00 & 1.00 \\
\hline 2 & $\begin{array}{l}\text { On the average, how many minutes does it } \\
\text { ake you to examine your breasts? Does it } \\
\text { take? }\end{array}$ & .06 & .92 & .24 & .27 & .86 \\
\hline 3 & $\begin{array}{l}\text { When doing self-examination, how do you } \\
\text { feel your breasts? Do you feel with the }\end{array}$ & .28 & .94 & .45 & .24 & .66 \\
\hline
\end{tabular}




\begin{tabular}{|c|c|c|c|c|c|c|}
\hline 4 & $\begin{array}{l}\text { When you examine your breasts, how often } \\
\text { do you look at your breasts in the mirror } \\
\text { with your hands on your hips? Do you? }\end{array}$ & .00 & .88 & .00 & .33 & .88 \\
\hline 5 & $\begin{array}{l}\text { How often do you examine your breasts in } \\
\text { the mirror by raising your hands over your } \\
\text { head and looking at your breasts? Do you? }\end{array}$ & .00 & 1.00 & .00 & .00 & 1.00 \\
\hline 6 & $\begin{array}{l}\text { When you examine your breasts, how often } \\
\text { do you squeeze your nipples and look for } \\
\text { discharge? Do you? }\end{array}$ & .00 & 1.00 & .00 & .00 & 1.00 \\
\hline 7 & $\begin{array}{l}\text { When you examine your breasts, how often } \\
\text { do you feel your breasts by examining in a } \\
\text { circular motion or a pattern which allows } \\
\text { you to cover the entire breast? Do you }\end{array}$ & .00 & 1.00 & .00 & .00 & 1.00 \\
\hline 8 & $\begin{array}{l}\text { When you examine your breasts, how often } \\
\text { do you feel the area under your arms to the } \\
\text { edge of your breasts? Do you? }\end{array}$ & .00 & 1.00 & .00 & .00 & 1.00 \\
\hline 9 & $\begin{array}{l}\text { When examining your breasts, how often } \\
\text { do you examine your ' breasts while } \\
\text { standing? Do you? }\end{array}$ & .00 & 1.00 & .00 & .00 & 1.00 \\
\hline 10 & $\begin{array}{l}\text { When examining your breasts, how often } \\
\text { do you examine each breast while lying } \\
\text { down with a pillow under the shoulder of } \\
\text { the breast being examined? Do you? }\end{array}$ & .00 & .98 & .00 & .14 & .98 \\
\hline 11 & I feel funny doing breast self-examination. & .00 & 1.00 & .00 & .00 & 1.00 \\
\hline 12 & $\begin{array}{l}\text { Doing breast self-examination during the } \\
\text { next year will make me worry about breast } \\
\text { cancer. }\end{array}$ & .98 & 1.00 & .14 & .00 & .02 \\
\hline 13 & $\begin{array}{llll}\begin{array}{l}\text { Breast } \\
\text { embarrassing to me. }\end{array} & \text { will } & \text { be } \\
\text { examination } & & \text { lo }\end{array}$ & .96 & 1.00 & .20 & .00 & .04 \\
\hline 14 & $\begin{array}{l}\text { Doing monthly breast self-examination } \\
\text { will take too much time. }\end{array}$ & 1.00 & 1.00 & .00 & .00 & .00 \\
\hline 15 & $\begin{array}{l}\text { Doing breast self-examination will be } \\
\text { unpleasant }\end{array}$ & 1.00 & 1.00 & .00 & .00 & .00 \\
\hline 16 & $\begin{array}{l}\text { I don't have enough privacy to do monthly } \\
\text { breast self-examination. }\end{array}$ & 1.00 & .98 & .00 & .14 & $\begin{array}{l}.02 \\
\end{array}$ \\
\hline 17 & $\begin{array}{l}\text { I know how to perform breast self- } \\
\text { examination }\end{array}$ & .00 & 1.00 & .00 & .00 & 1.00 \\
\hline 18 & $\begin{array}{l}\text { I am confident I can perform breast self- } \\
\text { examination correctly. }\end{array}$ & .16 & 1.00 & .37 & .00 & .84 \\
\hline 19 & $\begin{array}{l}\text { If were to develop breast cancer, I would } \\
\text { be able to find a lump by performing breast } \\
\text { self-examination. }\end{array}$ & .02 & 1.00 & .14 & .00 & .98 \\
\hline 20 & $\begin{array}{l}\text { I am able to find a breast lump if I practice } \\
\text { breast self-examination alone }\end{array}$ & .06 & 1.00 & .24 & .00 & .94 \\
\hline 21 & $\begin{array}{l}\text { I am able to find a breast lump which is the } \\
\text { size of a quarter. }\end{array}$ & .00 & 1.00 & .00 & .00 & 1.00 \\
\hline 22 & $\begin{array}{l}\text { I am able to find a breast lump which is the } \\
\text { size of a dime. }\end{array}$ & .00 & .98 & .00 & .14 & .98 \\
\hline 23 & $\begin{array}{l}\text { I am able to find a breast lump which is the } \\
\text { size of a pea }\end{array}$ & .00 & .96 & .00 & 1.98 & .96 \\
\hline
\end{tabular}




\begin{tabular}{|l|l|l|l|l|l|l|}
\hline 24 & $\begin{array}{l}\text { I am sure of the steps to follow for doing } \\
\text { breast self-examination }\end{array}$ & .06 & 1.00 & .24 & .00 & .94 \\
\hline 25 & $\begin{array}{l}\text { I am able to identify normal and abnormal } \\
\text { breast tissue when I do breast self- } \\
\text { examination. }\end{array}$ & & & & & \\
\hline 26 & $\begin{array}{l}\text { When looking in the mirror I can recognize } \\
\text { abnormal changes in my breast }\end{array}$ & .50 & 1.00 & .51 & .00 & .50 \\
\hline 27 & $\begin{array}{l}\text { I can use the correct part of my fingers } \\
\text { when I examine my breasts }\end{array}$ & .12 & 1.00 & .33 & .00 & .88 \\
\hline
\end{tabular}

\section{DISCUSSION}

The breast self examination scale which is used in this study was developed in 1984 by Champion the complete reevaluation and updating it was completed in 1992. In this study 50 women were participated. total 50 participants were women $(100 \%)$. Age group of women was $15-55$ years. 13 participants is from age group of 15-25 (26.0\%), 9 participants is from age group of $26-35(18.0 \%), 14$ participants is from age group of 36-45 (28.0\%), and 14 participants is from age group of 46-55 (28.0\%). Occupation of women was arranged in 3 groups' student, working and housewives (table 2). The cumulative mean of occupation was $1.20(\mathrm{SD}=.452) .41$ participant were students (82.0\%), 8 were working (16\%), and 1 was housewife (2\%).38 participants were single (76.0\%) and 12 were married (24\%).The need to evaluate the knowledge /attitudes and practice of Breast Self Examination among female (Ayed et al., 2015). In this study there is highly significant difference regarding knowledge about brat self examination in pre and post data. The mean score of pre data on knowledge of breast self examination were .2742 (SD) and mean score of post data were $.9852(\mathrm{SD}=.02993)$. the paired difference of mean was .000 with $95 \%$ confidence which is significant and reject the null hypothesis and accept the alternative hypothesis which is there is impact of breast self examination education on breast self examination practice. In current study findings related to knowledge scores with paired't' test was significant at $\mathrm{p}<0.05$ level $(\mathrm{p}=<0.001)$. And findings related to technique scores with paired't' test was significant at $p<0.05$ level $(p=<0.001)$. Thus showed that the knowledge about breast self examination is significant.

\section{LIMITATIONS}

The sample size of study was 50 which is not enough to generalize it to all population. It should be large sample size to generalize on all population. The next researcher should be choosing large sample size.

Incorporation of breast cancer programs into the school \& university programs.

Governmental and nongovernmental support for the female is needed to facilitate and continues early screening breast cancer.

$\checkmark$ Co-ordinate with mass media to increase awareness about breast cancer and methods.

\section{CONCLUSION}

Breast self examination is strategy to early detect the breast cancer. Although, in my sample there was lack of knowledge and practice of breast self examination which is observed from pre data. Therefore a teaching was given on breast self examination method, techniques and consideration. And post data was collected from this sample; there was highly significance difference in pre and post data.

\section{ACKNOWLADGMENT}

There is great thanks and appreciation to the participants and institute faculty who give me opportunity to do this research.

\section{REFERENCES}

[1] Albrecht, T. C. (1994). The impact of breast self-examination education on breast self-examination practices. Montana State University-Bozeman, College of Nursing.

[2] Anjum, F., Razvi, N., Maqbool, A., \& Jahan, N. (2017). A REVIEW OF BREAST CANCER RISK FACTORS. Universal Journal of Pharmaceutical Research.

[3] Ayed, A., Eqtait, F., Harazneh, L., Fashafsheh, I., Nazzal, S., Talahmeh, B., ... Awawdeh, R. (2015). Breast Self-Examination in Terms of Knowledge, Attitude, and Practice among Nursing Students of Arab American University/Jenin. Journal of Education and Practice, 6(4), 37-47.

[4] Eittah, H., Awed, H., \& Bukhary, Z. (2014). Effect of Health Education on Raising Female Students Awareness' Regarding Breast Cancer at Saudi Arabia. Journal of Natural Sciences Research, 4(9), 1-12.

[5] Mone, A., \& Kharde, S. (2018). A STUDY TO EVALUATE THE EFFECTIVENESS OF STRUCTURED DEMONSTRATION PROGRAMME ON KNOWLEDGE AND TECHNIQUE OF BREAST SELF EXAMINATION (BSE) AMONG COLLEGE GIRLS REGARDING EARLY DETECTION OF BREAST CANCER IN SELECTED DEGREE COLLEGE AT BELAGAVI KARNATAKA. GLOBAL JOURNAL FOR RESEARCH ANALYSIS, 7(6).

[6] Muchirevesi, S. S. (2016). Knowledge and practices of breast selfexamination among women admitted at a private clinic, Zimbabwe.

[7] Sarwar, M. Z., Shah, S. F. H., Yousaf, M. R., Ahmad, Q. A., \& Khan, S. A. (2015). Knowledge, attitude and practices amongst the Pakistani females towards breast cancer screening programme. screening, 8, 17-19.

[8] Tabari, F., Abbaszadeh, R., Torabi, S., \& Amini, F. (2017). Barriers of breast self-examination: A review study from Iranian researchers. BALI MEDICAL JOURNAL, 6(3), 562-568. 


\section{AUTHORS}

First Author - Iqra Aqeel, Lahore School of Nursing, Name of organization, The University of Lahore, Lahore, Pakistan, Iqraaqee1454@gmail.com
Second Author - Miss Iram, Dept. Lahore School of Nursing, Name of organization, The University of Lahore, Lahore, Pakistan 